\section{ТУВИНСКИЙ ЯЗЫК КАК СРЕДСТВО ОБЩЕНИЯ ТУВИНЦЕВ: ПРОБЛЕМЫ И ПЕРСПЕКТИВЫ}

\author{
Надежда Ч. Серээдар \\ Тувинский институт гуманитарных \\ и прикладных социально- \\ экономических исследований, \\ Российская Федерация
}

\section{TUVAN LANGUAGE AS MEANS OF COMMUNICATION AMONG TUVANS: PROBLEMS AND PROSPECTS}

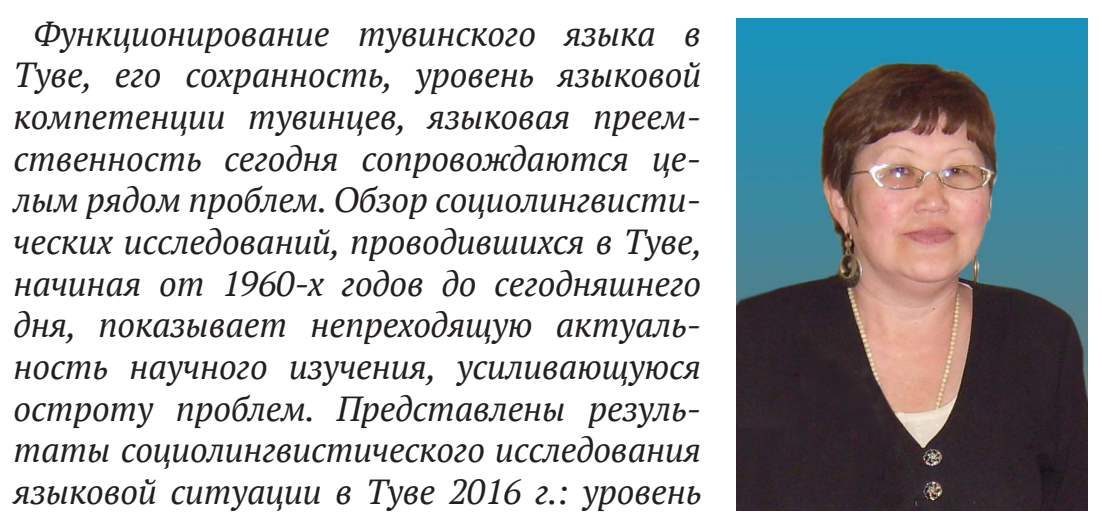
языковой компетенции тувинцев во владении тувинским языком и анализ его зависимости от различных социально-демографических характеристик испытуемых. В исследовании приняли участие 2500 респондентов тувинцев Тувы из числа трудоспособного населения разных возрастных групп. Исследование проводили сотрудники сектора языка Тувинского института гуманитарных и прикладных социально-экономических исследований.

Полученные результаты очевидно обусловлены историческими и поколенческими особенностями. У респондентов старшего поколения 50-60 лет языковая компетенция формировалась в период, когда в тувинских школах преподавание до 7 класса включительно велось на тувинском языке.
Nadezhda Ch. Sereedar

Tuvan Institute for Humanities and Applied Socio-Economic Studies, Russian Federation

The functioning of Tuvan language in the Republic of Tuva and its preservation, as well as the level of the linguistic competence of Tuvans and linguistic continuity - all of these factors are now accompanied by a host of problems. Reviews of sociolinguistic studies in Tuva, from the 1960s to our days, have shown the undying urgency of academic research of the ever increasing acuteness of these issues. The article presents the outcomes of a sociolinguistic study of the linguistic situation in Tuva (2016). The study was focused on measuring the linguistic competence of Tuvans in the command of their mother tongue and analyzing its dependence on various social and demographic indicators. The study was based on the survey of 2500 Tuvan respondents of various age groups within the working age and held by the staff researchers from the Sector of Language, Tuvan Institute for Humanities and Applied SocioEconomic Studies.

The outcomes of the survey reveal a marked dependence on the historical and generational factors. The elder generation's (aged 50-60) linguistic competence was formed in the period

Серээдар Надежда Чылбаковна - кандидат филологических наук, ведущий научный сотрудник, заведующая сектором языка и монголоведения Тувинского института гуманитарных и прикладных социально-экономических исследований. Адрес: 667000, Россия, г. Кызыл, ул. Кочетова, д. 4. Тел.: +7 (983) 518-03-38. Эл. адрес: sereedar.62@mail.ru

Sereedar Nadezhda Chylbakovna, Candidate of Philology, Leading Researcher, Chief, Language and Mongolian studies sector, Tuvan Institute of Human and Applied Socio-Economic Studies. Postal address: 4, Kochetova Str., 667000, Kyzyl, Russian Federation. Tel.: +7 (983) 518-03-38. E-mail: sereedar.62@mail.ru 
Это сыграло решающую роль в их овладении нормами литературного языка. Более слабое знание тувинским языком выявлено у лии, 14-18 лет. При этом 15\% из этой группы не считают нужным сохранение тувинского языка. Перепад значений обусловлен изменением языковой ситуации и усилением роли русского языка в Туве в современное время. Молодежь не признает родной язык как социально престижный язык.

Тувинский язык также не получил широкого распространения в сферах управления и делопроизводства, в СМИ преимущественное использование тувинского языка приходится на газетную периодику. У населения практически нет принципиального отказа от передачи родного языка. Но считается необходимым, чтобы дети в первую очередь овладели русским языком, потому что образование идет только на русском языке.

Автор полагает, что мириться с существующим положением нельзя. Обучение языку нужно начинать в раннем детстве. Ведущая роль должна принадлежать сфере семейного общения, дошкольного воспитания и школьного образования.

Ключевые слова: тувинский язык; Тува; тувинцы; социолингвистика; языковая компетенция; государственный язык; общественное мнение; поколение; СМИ when Tuvan schools (through Grade 7) taught all subjects in Tuvan. This played the crucial role in their command of Tuvan literary language and its norms. Respondents aged 14-18 showed a weaker command of the language, with $15 \%$ of them deeming the preservation of Tuvan language unnecessary. This substantial gap in attitudes is due to change in the linguistic situation and the increasing importance of the Russian language in contemporary Tuva. The younger generation recognizes the social prestige of the mother tongue.

Tuvan language failed to find wide use in public administration and bookkeeping. Of all mass media, Tuvan is mainly used in newspapers. Tuvan speakers show no determination to stop the transfer of the mother tongue to younger generations, but they consider it important that they should master the Russian language, as the education is now offered in Russian only.

The author believes that it would be wrong to put up with the status quo. Teaching language should be started in early childhood, with the leading role belonging to communication within the family, pre-school and school education.

Keywords: Tuvan language; Tuva; Tuvans; sociolinguistics; linguistic competence; state language; public opinion; generation; mass media

\section{Введение}

Титульным этносом и этническим большинством в Республике Тыва (Туве) являются тувинцы, носители тувинского языка. По итогам Всероссийской переписи населения 2010 г. все население Тувы составило 307930 чел., из них тувинцев 249299 чел. (4. Население по национальности ..., Электр. ресурс), т. е. 81\%. По всей Российской Федерации зафиксировано 263934 тувинцев (там же). Следует отметить, что кроме территории Тувы этнолокальные (субэтнические) группы тувинцев проживают на территории Красноярского края, Синьцзян-Уйгурского автономного округа Китая и северо-западной части Монголии (Ламажаа, 2017: Электр. ресурс).

По Конституции (Основному Закону) Республики Тыва 2001 г. (ст. 5.1) государственными языками считаются русский и тувинский языки (Конституция ..., Электр. ресурс). Русский язык закреплен как общефедеральный государственный язык и является языком межнационального общения, средством приобщения к культурам разных народов нашей страны. Безусловно, он доминирует во всех сферах общественной жизни. При этом, согласно ст. 5.2 Конституции Тувы, республика «обеспечивает гарантии соблюдения прав всех национальностей на сохранение родного языка, создания условий для его изучения и развития» (там же). 
В социальной практике Тувы функционирование тувинского языка, его сохранность, уровень языковой компетенции тувинцев, языковая преемственность сталкивается с целым рядом проблем. Поэтому несмотря на численное большинство в республике тувинцев, владение большинством из них родного языка, проблема тувинского языка остается весьма актуальной. Задачей настоящей статьи является определить уровень языковой компетенции тувинцев во владении тувинским языком и проанализировать его зависимость от различных социально-демографических характеристик испытуемых. Иными словами, мы представим социолингвистическое исследование, основанное как на анализе научной литературы, так и на результатах авторского эмпирического исследования 2016 года.

\section{Степень изученности вопроса}

Социолингвистическое изучение тувинского языка началось с конца 19601970-х гг. Так, первый социолингвистический опрос тувинского населения был проведен в 1967 г. сотрудниками Института истории, филологии и философии СО АН СССР под общим руководством профессора В. А. Аврорина, известного специалиста по социолингвистике.

Целью исследования было получение данных о соотношении функций тувинского и русского языков в жизни тувинцев. В советский период тувинский язык оставался основным средством коммуникации среди тувинцев. Результаты опроса подтвердили это, показав, что он также доминирует во всех сферах личной и общественной жизни тувинцев-сельчан. Так, в семейном кругу на родном языке общались с дошкольниками 99,8\% и со школьниками - 100\% родителей. В процессе трудовой деятельности 99,5\% работающего населения предпочитало общаться на тувинском языке. Также $88,2 \%$ респондентов было понятнее читать литературу, слушать лекции и смотреть театральные постановки на родном языке. Было выявлено, что на селе родным тувинский язык признали все тувинцы, а в городе - 88,3\%, наряду с родным, русский язык знали и использовали на селе $-60,8 \%$, в городе - 88,7\% тувинцев (Сердобов, 1968: 83-86; Сердобов, 1980: 24; Аврорин, 1975a).

Изучением тувинско-русских языковых контактов и типов двуязычия в Туве, общественных функций тувинского и русского языков занимались в XX в. такие ученые-тувиноведы, как Ш. Ч. Сат, Д. А. Монгуш, Б. И. Татаринцев и др.

Одним из первых социолингвистических исследований тувинского языка следует считать диссертацию на соискание ученой степени доктора наук 1970-х годов Ш. Ч. Сата «Формирование и развитие тувинского национального литературного языка», которую он практически сразу издал как монографию (Сат, 1973). В своем труде он подробно изучил социальные и коммуникативные 
функции тувинского языка, историю становления его литературной формы и формирования стилей, основные сферы его функционирования и соотношение с русским языком.

В 1990-е годы старший научный сотрудник сектора языка Тувинского института гуманитарных исследований (ныне - Тувинского института гуманитарных и прикладных социально-экономических исследований, ТИГПИ) М. Б. Мартаноол занималась социолингвистикой тувинского языка. Этой теме посвящены разные ее статьи. К ним относятся такие статьи, как «Проблемы и перспективы тувинского языка» (Мартан-оол, 2000а), «О состоянии развития и уровня двуязычия в Республике Тыва» (Мартан-оол, 1992), «Языки и языковая ситуация в Республике Тыва» (Мартан-оол, 2005), «Сферы функционирования тувинского языка» (Мартан-оол, 2000b) и др. В 2014 г. вышел в свет сборник статей М. Б. Мартан-оол, посвященный к юбилею ученого, в который вошли авторские статьи и по социолингвистике (Мартан-оол, 2014). В данном направлении она пишет о разных функциях тувинского языка в средствах массовой информации, в сфере науки, в сфере культуры, в сфере законодательных органов и судопроизводства. Она отмечает, что в сфере законодательных органов и судопроизводства тувинскому языку чаще всего отводится пассивная роль в связи с невостребованностью юридических документов, в средствах массовой информации не в полной мере используются потенциальные возможности тувинского языка и, как следствие этого, не развит язык политиков и стиль публичных выступлений.

В 1997-1998 гг. Г. М. Селиверстова провела этносоциологическое исследование с целью изучения сфер функционирования русского, тувинского языков, а также языков других народов, проживающих в Туве, изучения взаимодействия языков и ценностных ориентаций носителей того или иного языка (Селиверстова, 2008: Электр. ресурс). Среди 286 проанкетированных представителей коренной национальности она не нашла ни одного человека, который был бы против изучения русского языка в тувинской школе. Если в 1993 г. 100\% опрошенных считали, что языком обучения в тувинской национальной школе должен быть родной язык, спустя 5-6 лет так стали считать только 15,3 процента; по мнению $47,5 \%$, обучение должно вестись на родном и русском языках; 36,3\% предлагали уже с 1-го класса вести предметы на русском языке, оставив родной язык как предмет; 0,9\% предложили вести обучение на родном и английском языках. Автор отметила резкий рост потребности у тувинских родителей и учащихся на преподавание русского языка русскими учителями в тувинской национальной школе и на русскую школу в целом, поскольку хорошие знания языка межнационального общения дают большие возможности для продолжения образования.

Из недавних социолингвистических исследований следует упомянуть социологическое исследование городского населения Тувы «Тувинский язык и письменность в общественном мнении кызылчан», проведенное сектором социологии ТИГПИ под руководством В. С. Кан, отдельные результаты которого 
опубликованы в республиканской прессе (Кан, 2010: Электр. ресурс). Опрос был приурочен к 80-летнему юбилею тувинской письменности, который отмечался научной общественностью Тувы на Международной научной конференции «Тувинская письменность и вопросы исследования письменностей и письменных памятников России и Центрально-Азиатского региона» в 2010 г.

Тогда было опрошено 302 жителя г. Кызыла по репрезентативной выборке. Исследователи выясняли базовые знания кызылчан о том, когда была создана письменность, что для них значит тувинский язык, считают ли его родным, насколько оценивают уровень владения языком, где он применяется, какие проблемы волнуют людей и какие мероприятия они предлагают для развития тувинского языка. Опрос показал недостаточно высокий уровень информированности респондентов о тувинском языке, о том, что он является государственным языком, о том, что он относится к тюркским языкам. Выяснилось, что большая часть участников опроса говорит на родном языке именно в семье. Авторы работы отметили, что многие дети и подростки не владеют литературным тувинским языком, а часть из них не знает родного языка даже на разговорном уровне, предпочитая тувинскому русский язык.

Интересные исследования проводились другими авторами. Например, в 2013 г. защитила кандидатскую диссертацию по филологии, с работой по социопсихолингвистическим аспектам современной языковой ситуации в Туве Ч. С. Цыбенова (Цыбенова, 2013). Социолингвистические вопросы в своих исследованиях поднимает М. В. Бавуу-Сюрюн (напр.: Бавуу-Сюрюн, 2010: Электр. ресурс). Вопросы функционирования тувинского языка входят в поле внимание исследователей иных и общих территорий (Боргоякова, 2002ab; Журавель, 2015; Каксин, 2013).

Очевидно, что проблема функционирования и преемственности тувинского языка в Туве сохраняется и, возможно, даже усугубляется; филологи продолжают активно изучать процессы, высказывая в том числе свои опасения и тревоги. Поэтому в 2016 г. мы провели свое исследование. Целью его являлся сбор информации для исследования функционирования тувинского языка и фиксации его современного состояния.

\section{Знание тувинского языка и его востребованность}

В нашем социолингвистическом опросе приняли участие 2500 респондентов тувинской национальности различных возрастных и социальных групп трудопособного населения, проживающего на территории Тувы (в составе которых мы рассматривали 548 респондентов в возрастной группе от 14 до 18 лет, 548 респондентов взрослых от 19 до 59 лет и старше). В том числе это были учащиеся школ, лицеев, колледжей, вузов, государственные служащие, предприниматели 
и др. В анкетировании участвовали сотрудники сектора языка ТИГПИ: П. С. Серен, О. М. Саая, К.-М. А. Симчит, С. Д. Саая.

Методами исследования выступили фронтальное, индивидуальное анкетирование, ассоциативный эксперимент и сравнительный метод. Кодировка анкет проводилась по методике социолингвистического исследования, полученные результаты были обработаны с помощью программы «SPSS».

Определяя теоретические положения нашего исследования, мы исходили из определения языковой ситуации В. А. Аврорина: «Языковая ситуация - это конкретный тип взаимодействия языков и разных форм их существования в общественной жизни каждого народа на данном этапе его исторического развития» (Аврорин, 1975a: 22). Обязательными при изучении любой языковой ситуации, по В. А. Аврорину, являются следующие объекты: 1) социальные условия функционирования языка, 2) сферы и среды употребления языка, 3) формы существования языка, 4) функции языка (там же: 120).

Прежде всего, анкета содержала 37 закрытых вопросов, которые сводились в 4 группы: 1-я группа - адресная: а) республика; 2-я группа - паспортная, устанавливающая национальность, пол, возраст, образование, место работы, род деятельности, время проживания в данной местности и родной язык информанта; 3-я группа - это вопросы, выясняющие степень владения тем или иным языком (родным, русским, каким-либо иным, одним или несколькими), а также употребительность в разных сферах жизни тех или иных языков; эта важнейшая группа содержит наибольшее число вопросов (18); вопросы такие: а) на каких языках, помимо родного, информант может только понимать чужую речь, или также и разговаривать, или также читать и писать; б) на каком языке он говорил до поступления в школу и на каком начал обучаться в школе; в) на каком языке обычно говорит в семье с детьми-дошкольниками, с детьми-школьниками, со взрослыми, на работе или в школе, в прочих случаях с людьми своей национальности и с людьми иных национальностей; г) на каком языке для него понятнее читать, слушать лекции, доклады, концерты и спектакли, удобнее выступать на собраниях, писать или диктовать письма людям своей или иной национальности; д) нужны ли ему пояснения на родном языке к кинофильмам (имеются в виду фильмы с русским текстом); 4-я группа - вопросы, выявляющие пожелания в отношении использования тех или иных языков: а) на каком языке, по мнению информанта, следует говорить с детьми в дошкольных учреждениях; б) на каком языке вести обучение в первом классе, в других классах начальной школы, в средней школе; в) нужно ли преподавать родной язык как предмет в школе и в средних специальных учебных заведениях (см.: Аврорин, 1975a: 252-253)

Дополняли анкету 28 вопросов социолингвистического характера и лингвистического. Вопросы были направлены на определение социальных признаков респондентов (год рождения, место рождения, пол, образование, род занятий), 
а также на фиксацию социолингвистических параметров (родной язык, родной язык родителей, последовательность усвоения языков, степень и формы владения языками, сферы использования языков), необходимые для определения языковой компетенции, языковых предпочтений респондентов и выявления сфер функционирования языков.

Далее был включен ряд вопросов оценочного характера, в частности, направленный на оценку престижности того или иного языка для самих респондентов и их детей, на выявление отношения к введению тувинского языка в различные сферы, а также на знание и оценку закона «О языках в Республике Тыва». В конце социолингвистической части были приведены вопросы, выявляющие этноконсолидирующие признаки и этнические ценности тувинского этноса, а также вопрос о роли языка как этноидентифицирующего признака. Лингвистическая часть включала четыре задания: перевод словосочетаний с разным семантическим значением с русского на тувинский язык, ассоциативный эксперимент и подбор недостающей части парных слов. Эти вопросы проверяли не только языковое чутье и догадку респондентов, но были направлены и на получение представлений о языковой картине мира, о языковом сознании тувинцев. Если первая часть анкеты предполагала субъективную оценку респондентов, то вторая часть была направлена на выявление объективного знания тувинского языка респондентами.

Основная часть анкеты - лингвистическая, анализ которой позволяет проследить тенденции развития внутренней структуры тувинского языка в современ-

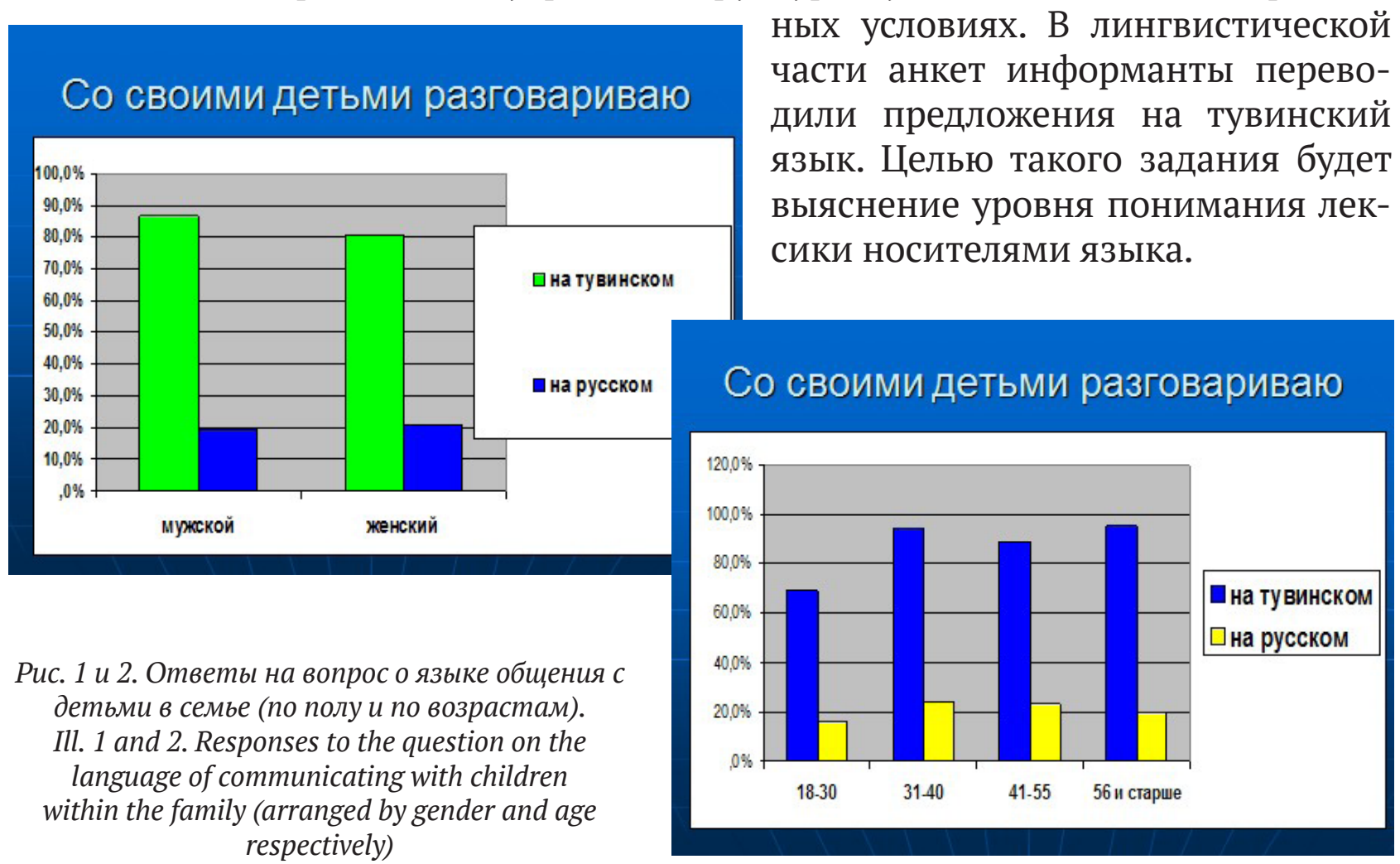


Владение языком является одним из ключевых моментов языковой политики. Также владение языком молодым поколением является одним из необходимых условий его жизнеспособности. Передача языка и установка на его изучение, как правило, формируется в рамках семьи, в частности родителями.

На вопрос «На каком языке родители разговаривают со своими детьми?» более 20\% из респондентов возрастных категорий: 19-30 лет, 31-40 лет, 41-55 лет, 56 и старше разговаривают на русском языке (см. рис. 1 и 2).

Особенности функционального соотношения тувинского и русского языков выявлялись в ходе социолингвистического опроса при помощи вопроса «На каком языке вы предпочитаете говорить в следующих ситуациях?» Были сформулированы сферы общения: 1) сфера общественно-производственной деятельности (общение на работе, в учебном заведении, в государственных учреждениях и при записи); 2) сфера семейно-бытового и межличностного общения (общение в семье, с друзьями, с родственниками, в культовых и общественных местах, личная переписка); 3) сфера удовлетворения информационных и эстетических потребностей.

Полученные нами результаты очевидно обусловлены историческими и поколенческими особенностями.

У респондентов, родившихся с 1951 по 1960 гг., языковая компетенция формировалась в период, когда в тувинских школах преподавание до 7 класса включительно велось на тувинском языке, кроме русского языка и литературы. Именно обучение детей на родном языке сыграло решающую роль в их овладении нормами литературного языка (Сат, 1973: 62). Введение всеобщего семилетнего образования на родном языке привело к расширению не только сети школ, но и охвату обучением абсолютного большинства детей соответствующего возраста (Монгуш, 2009: 40). Следует добавить, что в Туве преподавание всех предметов (кроме родного языка) в 8-10 классах и в средних специальных учебных заведениях с начала $1950-\mathrm{x}$ годов стало вестись также и на русском языке (Монгуш, Татаринцев, 1985: 7). После

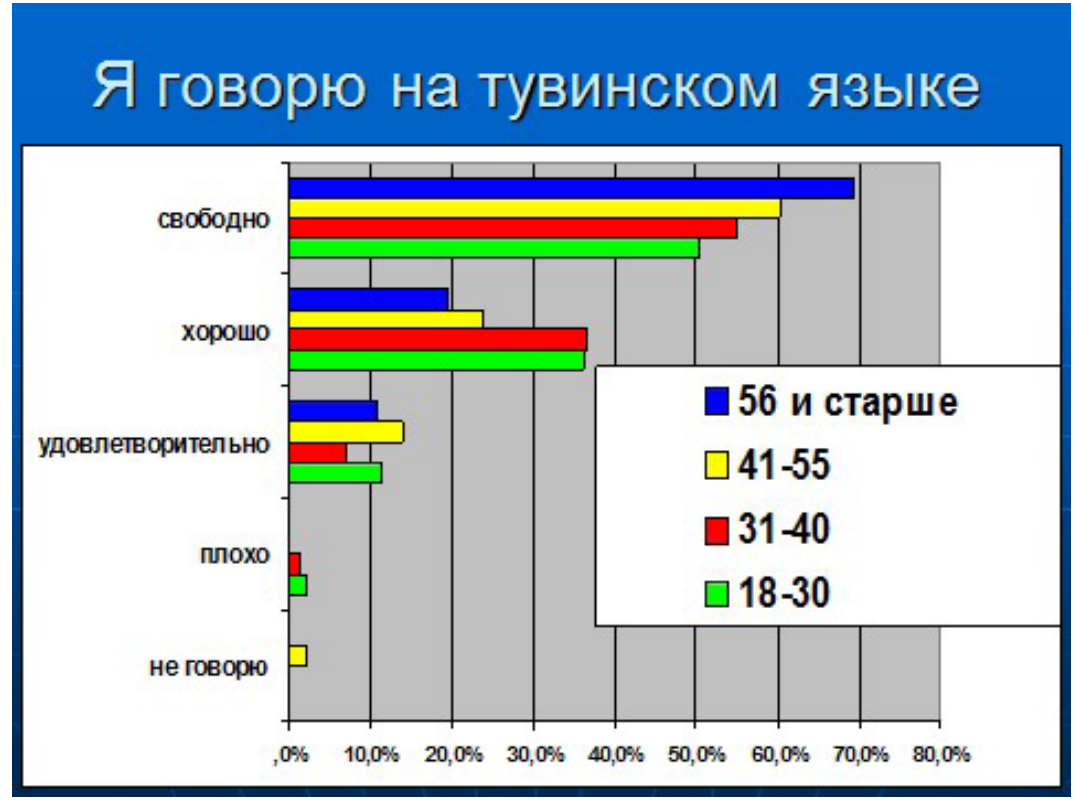

Рис. 3. Степень владения тувинским языком у представителей старших поколений. Ill.3 Command of Tuvan language by elder generations of Tuvans 
распада Советского Союза, когда в 1992 г. был принят Закон «О языках в Тувинской АССР» и развернулся процесс национального возрождения, происходило постепенное повышение уровня коренизации тувинской школы включительно по 9-й класс (Селиверстова, 2008: Электр. ресурс).

Из числа старших респондентов (с 19 по 56 и старше лет) родным языком считают тувинский $-98,3 \%$ (разделение ответов на степени владения тувинским языком - см. на диаграмме в рис. 3).

Более слабое знание тувинским языком (кроме устных форм) выявлено у лиц, родившихся с 1999 по 2004 гг. Очевидно перепад значений у данной группы обусловлен изменением языковой ситуации и усилением роли русского языка в современное время.

Анализ лингвистической части анкет респондентов 14-18 лет показывает распространенные ошибки в составлении и написании сложных слов, в написании составных глаголов, в выполнении задания с ассоциациями, в отражении в письме звуков тувинского языка, в ошибках переводов с русского на тувинский язык и др.

Значение тувинского языка для будущих поколений выяснялось вопросом «Необходимо ли знание тувинского языка современному человеку Республики Тыва?» Тревожным фактом мы можем считать, что более 15\% респондентов с 14 до 18 лет ответили «Мне безразлично, нет». При этом 20\% уверенно ответили - «Да».

\section{Место тувинского языка в общественной жизни}

Тувинский язык функционирует как средство повседневного общения среди тувинского населения. Но при этом, как мы выяснили, респонденты в возрасте от 31 до 40 плохо передают язык следующему поколению. В результате респонденты 14-18 лет родным языком называют русский язык, хотя язык родителей - тувинский. Он не признается как социально престижный язык, поэтому социальный статус русского языка выше.

В нашем опросе мы также предложили респондентам поразмышлять на темы снижения и повышения роли тувинского языка в общественной жизни. В частности, на вопрос «Почему тувинский язык не работает во всех сферах жизни как государственный» мы получили следующий спектр мнений (см. рис. 4).

Исследователи тувинского языка также отмечают, что в настоящее время тувинский язык не получил широкого распространения в сферах управления и делопроизводства (Бавуу-Сюрюн, 2010: Электр. ресурс). В сфере массовой коммуникации преимущественное использование тувинского языка приходится на газетную периодику. Несмотря на проблемы финансирования и сокращение тиражей в настоящий момент на тувинском языке издается 11 газет (4- респу- 
бликанского, 7 муниципального районного значения) и 2 журнала (литературно-художественный альманах «УлугХем» и научноме тодический журнал «Башкы»). Основной читательской аудиторией выступает старшее поколение. Молодежь предпочитает более современные способы коммуникации, например, Интернет.

у населения практически нет

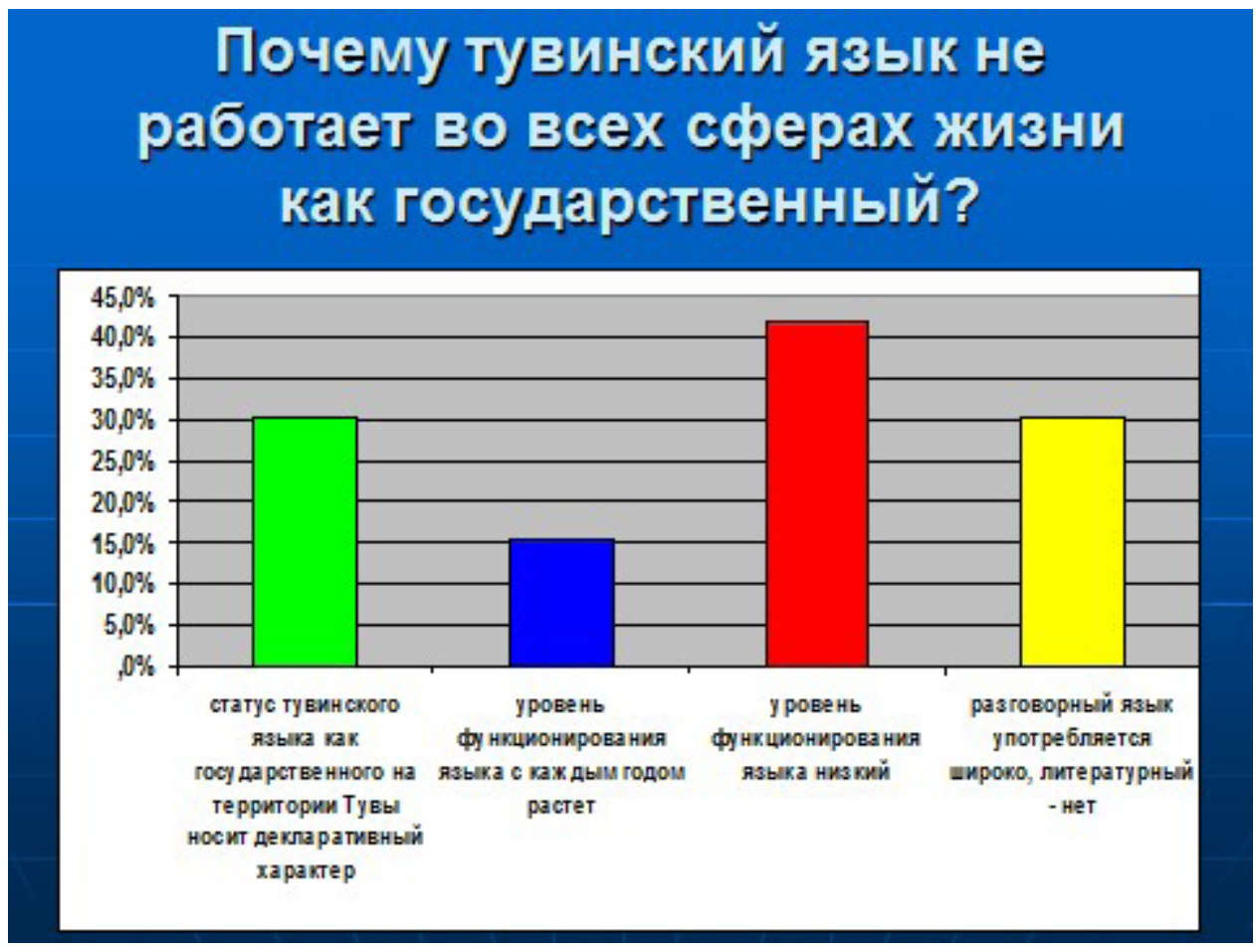

Рис. 4. Мнения респондентов о том, почему тувинский язык мало функционирует в общественных сферах.

Ill. 4. Respondents' opinions on why Tuvan language finds little use in the public sphere.

принципиального отказа от передачи родного языка. Но считается необходимым, чтобы дети в первую очередь овладели русским языком, потому что образование идет только на русском языке (детские сады, школа, затем - вузы). Считается, что тувинский язык дети каким-то образом изучат самостоятельно, стихийно в общении с родными, с бабушками и дедушками.

Мы полагаем, что мириться с существующим положением нельзя.

Лингвисты определяют пять ступеней процесса, когда язык находится в опасности. Первая ступень, когда все говорят на родном языке. Вторая ступень, когда на родном языке говорят меньше, простое большинство. Третья ступень, когда говорит преимущественно пожилое население, а молодежь использует меньше. Четвертая ступень - когда, намечается разрыв между поколениями, бабушка с внуком говорит уже не на родном языке. И пятая ступень, когда остается совсем мало носителей родного языка, нет его воспроизводства. Очевидно, что в соответствии с этой градацией тувинский язык неуклонно проходит ступени подобного регресса.

Необходимо настойчиво искать наиболее рациональные пути разрешения проблемы. Одним из таких путей, по моему глубокому убеждению, может явиться возврат к разумному использованию родного языка учащихся в начальных классах - в первом, в первых двух или трех в зависимости от конкретной об- 
становки, прежде всего в зависимости от реальной степени владения русским языком у поступающих в школу.

Под передачей языка мы также понимаем его активное знание и использование: ребенок должен свободно говорить на языке, быть в состоянии порождать различные конструкции. Нелепо думать, что работа на родных языках мешает овладению русским языком, мешает расширению кругозора. Как раз наоборот, широкое развитие просветительной работы на родных языках служит не только источником для приобретения знаний, но и непосредственным поводом к овладению русским языком.

Думается, что сложившийся к середине 1950-х годов порядок работы нерусских школ с преподаванием в начальных классах на родных языках вполне себя оправдал. Такой порядок заслуживал сохранения и дальнейшего совершенствования. Его достоинства заключались в том, что он, во-первых, создавал оптимальные условия для развития мыслительных способностей детей, ибо давно доказано, что эту цель способен обеспечить только родной язык; во-вторых, позволял вооружить детей хорошим знанием русского языка, на котором они продолжали обучение с третьего класса, и параллельно давать им начальное образование на родном языке; в-третьих, предупреждал опасность утраты детьми родного языка и тем самым разрыва связей между поколениями (Аврорин, 1975).

\section{Заключение}

Материалы анкетного опроса не могут дать полной картины языковой ситуации, но ряд вопросов они безусловно ставят. Тувинцы владеют своим родным тувинским языком достаточно хорошо, но социального престижа в нем не видят. Поэтому социальный статус русского языка выше, а тувинский язык в основном рассматривается как средство повседневного общения.

Мы убеждены, что обучение языку нужно начинать в раннем детстве, так как в более позднем возрасте эффективность процесса снижается. В обучение детей родному языку, передаче им народных обычаев и традиций ведущая роль принадлежит сфере семейного общения, дошкольного воспитания и школьного образования.

\section{СПИСОК ЛИТЕРАТУРЫ}

4. Население по национальности и владению русским языком по субъектам Российской Федерации [Электронный ресурс] // Всероссийская перепись населения 2010. URL: http://www.gks.ru/free_doc/new_site/perepis2010/croc/Documents/ Vol4/pub-04-04.pdf (дата обращения: 11.12.2017). 
Аврорин, В. А. (1975а) Проблемы изучения функциональной стороны языка (К вопросу о предмете социолингвистики). Л. : Наука. 276 с.

Аврорин, В. А. (1975b) О предмете социальной лингвистики // Вопросы языкознания. № 4. С.11-17.

Бавуу-Сюрюн, М. В. (2010) Тувинский язык на современном этапе [Электронный ресурс] // Новые исследования Тувы. № 3. URL: https://nit.tuva.asia/nit/ article/view/500 (дата обращения: 11.12.2017).

Боргоякова, Т. Г. (2002а) Развитие социальных функций государственных тюркских языков Республик Южной Сибири : автореф.... дис. д-ра филол. наук. M. 37 c.

Боргоякова, Т. Г. (2002b) Социолингвистические процессы в республиках Южной Сибири. Абакан : Хакас. гос. ун-т им. Н. Ф. Катанова. 166 с.

Журавель, Т. Н. (2015) Этноязыковая ситуация в Усинской долине Красноярского края : автореф. дис... канд. филол. наук. Красноярск. 23 с.

Каксин, А. Д. (2013) Хакасы: культурные традиции и их трансформация (конец XX - начало XXI в.). Абакан : Хакасское книжное издательство. 150 с.

Кан, В. С. (2010) Тувинский язык и письменность в общественном мнении кызылчан [Электронный ресурс] // Плюс Информ. 2 августа. URL: http://plusinform. ru/main/1669-sotsiologicheskie-issledovaniya.html (дата обращения: 12.12.2017).

Конституция Республики Тыва (принята Референдумом Республики Тыва 6 мая 2001 г.) (с изменениями и дополнениями) [Электронный ресурс] // Сайт Конституции Российской Федерации. URL: http://constitution.garant.ru/ region/cons_tiva/chapter/47ce20baf1ba0dde0c972b882bcd2a68/ (дата обращения: 11.12.2017).

Ламажаа, Ч. К. (2017) Проблемы определения и изучения субэтнических групп тувинцев [Электронный ресурс] // Новые исследования Тувы. № 1. URL: https:// nit.tuva.asia/nit/article/view/693 (дата обращения: 12.12.2017). DOI: 10.25178/ nit.2017.1.1

Мартан-оол, М. Б. (1992) О состоянии развития и уровня двуязычия в Республике Тува // Языковая ситуация в Российской Федерации / под ред. В. М. Солнцева. М. С. 115-119, 164-165.

Мартан-оол, М. Б. (2000а) Проблемы и перспективы тувинского языка // Языки народов России: перспективы развития: материалы международного семинара на рус., англ.языках (Элиста, Республика Калмыкия, 10-16 мая 1999 г.). Элиста. С.137-147, 405-413.

Мартан-оол, М. Б. (2000b) Сферы функционирования тувинского языка // Тезисы докладов научной конференции, посвященной 70-летию тувинской письменности / ред. Б. И. Татаринцев, М. Б. Мартан-оол. Кызыл. С. 59-64. 
Мартан-оол, М. Б. (2005) Языки и языковая ситуация в Республике Тыва // Гуманитарная наука Тувы на стыке веков: история, проблемы и перспективы развития. Кызыл. С. 60-64.

Мартан-оол, М. Б. (2001) Сферы функционирования тувинского языка // Гуманитарные исследования в Туве : сб. науч. статей / отв. ред. К. А. Бичелдей. М. : Изд-во РУДН. С. 43-56.

Мартан-оол, М. Б. (2014) Вопросы тувинского языка: диалектология, лексикография и социолингвистика: избранные научные труды / сост. Ч. Ч. Норбу. Абакан. 276 с.

Монгуш, Д. А. (2009) Тувинский язык и письменность: Избранные труды. Кызыл : ГУП РТ «Тываполиграф». 248 с.

Монгуш, Д. А., Татаринцев, Б. И. (1985) Проблемы изучения функционирования русского языка в Туве // Русский язык в Туве : сборник статей / отв. ред. Б. И. Татаринцев. Кызыл : б. и. 218 с. С. 3-15.

Сат, Ш. Ч. (1973) Формирование и развитие тувинского национального литературного языка. Кызыл : Тувинское книжное издательство. 193 с.

Селиверстова, Г. М. (2007) Родной язык не нужен? Как решить проблемы двуязычия [Электронный ресурс] // Учительская газета. 8 января. URL: http:/www. ug.ru/archive/22167 (дата обращения: 12.12.2017).

Сердобов, Н. А. (1968) К вопросу о некоторых социолого-лингвистических процессах в национальной консолидации тувинцев // Ученые записки Тувинского НИИЯЛИ. Кызыл. Вып. 13. С. 78-109.

Сердобов, Н. А. (1980) О роли языка и письменности в национальной консолидации тувинского народа // Тувинская письменность язык и литература / отв. ред. Ю. Л. Аранчын. Кызыл : Тувкнигоиздат. 131 с. С. 15-30.

Цыбенова, Ч. С. (2013) Современная языковая ситуация в Республике Тыва : социопсихолингвистический аспект : автореф. дис. ... канд. филол. наук. УланУдэ. 24 с.

Дата поступления: 15.01.2018 г.

\section{REFERENCES}

4. Naselenie po natsional'nosti i vladeniiu russkim iazykom po sub"ektam Rossiiskoi Federatsii [4. Population by nationality and Russian language proficiency, by subject of the Russian Federation]. Vserossiiskaia perepis' naseleniia 2010 [online] Available at http://www.gks.ru/free_doc/new_site/perepis2010/croc/Documents/Vol4/pub-04-04. pdf (access date: 11.12.2017). (In Russ.). 
Avrorin, V. A. (1975a) Problemy izucheniia funktsional'noi storony iazyka (K voprosu o predmete sotsiolingvistiki) [Issues of Studying the Functional Aspect of Language (On the Subject of Sociolinguistics)]. Leningrad, Nauka. 276 p. (In Russ.).

Avrorin, V. A. (1975b) O predmete sotsial'noi lingvistiki [On the Subject of Sociolinguistics]. Voprosy iazykoznaniia, no. 4, pp. 11-17. (In Russ.).

Bavuu-Surun, M. V. (2010) Tuvinskii iazyk na sovremennom etape [Tuvan language on modern stage: educational aspect]. The New Research of Tuva, no. 3 [online] Available at: https://nit.tuva.asia/nit/article/view/500 (access date: 11.12.2017). (In Russ.).

Borgoiakova, T. G. (2002a) Razvitie sotsial'nykh funktsii gosudarstvennykh tiurkskikh iazykov Respublik Iuzhnoi Sibiri [The Development of Social Functions of the State Turkic Languages of the Republics of Southern Siberia]: Thesis of Diss.... Doctor of Philology. Moscow. 37 p. (In Russ.).

Borgoiakova, T. G. (2002b) Sotsiolingvisticheskie protsessy v respublikakh Iuzhnoi Sibiri [Sociolinguistic Processes in the Republics of Southern Siberia]. Abakan, Khakas. gos. un-t im. N. F. Katanova. 166 p. (In Russ.).

Zhuravel', T. N. (2015) Etnoiazykovaia situatsiia v Usinskoi doline Krasnoiarskogo kraia [Ethnolinguistic Situation in the Usinsk valley, Krasnoiarsk krai]: Thesis of Diss.... Candidate of Philology. Krasnoiarsk. 23 p. (In Russ.).

Kaksin, A. D. (2013) Khakasy: kul'turnye traditsii i ikh transformatsiia (konets XX nachalo XXI v.) [The Khakas: Cultural Traditions and Their Transformation (late 20th early 21st century)]. Abakan, Khakasskoe knizhnoe izdatel'stvo. 150 p. (In Russ.).

Kan, V. S. (2010) Tuvinskii iazyk i pis'mennost' v obshchestvennom mnenii kyzylchan [Tuvan Language and Writing in the Public Opinion of Kyzyl]. Plius Inform, 2 August [online] Available at: http://plusinform.ru/main/1669-sotsiologicheskieissledovaniya.html (access date: 12.12.2017). (In Russ.).

Konstitutsiia Respubliki Tyva (priniata Referendumom Respubliki Tyva 6 maia 2001 g.) (s izmeneniiami i dopolneniiami) [Constitution of the Republic of Tuva (adopted by Referendum of the Republic of Tuva on May 6, 2001) (as amended)]. Sait Konstitutsii Rossiiskoi Federatsii [online] Available at: http://constitution.garant.ru/region/cons_tiva/ chapter/47ce20baf1ba0dde0c972b882bcd2a68/ (access date: 11.12.2017). (In Russ.).

Lamazhaa, Ch. K. (2017) Problemy opredeleniia i izucheniia subetnicheskikh grupp tuvintsev [Sub-ethnic Groups of the Tuvans: Problems of Definition and Research]. The New Research of Tuva, no. 1 [online] Available at: https://nit.tuva.asia/nit/article/ view/693 (access date: 12.12.2017). DOI: 10.25178/nit.2017.1.1 (In Russ.).

Martan-ool, M. B. (1992) O sostoianii razvitiia i urovnia dvuiazychiia v Respublike Tuva [The Status of Development and Level of Bilingualism in the Republic of Tuva]. In: Iazykovaia situatsiia $v$ Rossiiskoi Federatsii [The language situation in the Russian Federation]. Moscow. Pp. 115-119, 164-165. 
Martan-ool, M. B. (2000a) Problemy i perspektivy tuvinskogo iazyka [Problems and prospects of the Tuvan language]. In: Iazyki narodov Rossii: perspektivy razvitiia: materialy mezhdunarodnogo seminara na rus., angl.iazykakh (Elista, Respublika Kalmykiia, 10-16 maia 1999 g.) [Languages of the peoples of Russia: prospects of development: proceedings of the international seminar: in Russian and English languages (Elista, Republic of Kalmykia, 10-16 May 1999)]. Elista. Pp. 137-147, 405-413. (In Russ.).

Martan-ool, M. B. (2000b) Sfery funktsionirovaniia tuvinskogo iazyka [Areas of Functioning of the Tuvan Language]. In: Tezisy dokladov nauchnoi konferentsii, posviashchennoi 70-letiiu tuvinskoi pis'mennosti [Abstracts of Papers Presented at the Scientific Conference Devoted to the 70th Anniversary of Tuvan Writing] / ed. by B. I. Tatarintsev and M. B. Martan-ool. Kyzyl. Pp. 59-64. (In Russ.).

Martan-ool, M. B. (2005) Iazyki i iazykovaia situatsiia v Respublike Tyva [Languages and language situation in the Republic of Tuva]. In: Gumanitarnaia nauka Tuvy na styke vekov: istoriia, problemy i perspektivy razvitiia [The Humanities in Tuva at the Turn of the Century: History, Problems and Prospects]. Kyzyl. Pp. 60-64. (In Russ.).

Martan-ool, M. B. (2001) Sfery funktsionirovaniia tuvinskogo iazyka [Areas of Functioning of the Tuvan Language]. In: Gumanitarnye issledovaniia $v$ Tuve [Research in the Humanities in Tuva]: a collection of papers / ed. by K. A. Bicheldei. Moscow, RUDN Publ. Pp. 43-56. (In Russ.).

Martan-ool, M. B. (2014) Voprosy tuvinskogo iazyka: dialektologiia, leksikografiia i sotsiolingvistika: izbrannye nauchnye trudy [Issues of the Tuvan Language: Dialectology, Lexicography and Sociolinguistics: Selected Research Papers] / comp. by Ch. Ch. Norbu. Abakan. 276 p. (In Russ.).

Mongush, D. A.(2009) Tuvinskii iazyki pis'mennost': Izbrannye Trudy [Tuvan Language and Writing: Selected Works]. Kyzyl, GUP RT «Tyvapoligraf». 248 p. (In Russ.).

Mongush, D. A. and Tatarintsev, B. I. (1985) Problemy izucheniia funktsionirovaniia russkogo iazyka v Tuve [Problems of Studying the Functioning of the Russian Language in Tuva]. In: Russkii iazyk v Tuve : sbornik statei [Russian Language in Tuva: A Collection of Articles] / ed. by B. I. Tatarintsev. Kyzyl, s. n. 218 p. Pp. 3-15. (In Russ.).

Sat, Sh. Ch. (1973) Formirovanie i razvitie tuvinskogo natsional'nogo literaturnogo iazyka [The Formation and Development of the Tuvan National Literary Language]. Kyzyl, Tuvinskoe knizhnoe izdatel'stvo. 193 p. (In Russ.).

Seliverstova, G.M.(2007) Rodnoi iazyk ne nuzhen? Kakreshit' problemy dvuiazychiia [No Need for a Mother Tongue? How to Solve the Problems of Bilingualism]. Uchitel'skaia gazeta, 8 January [online] Available at: http://www.ug.ru/archive/22167 (access date: 12.12.2017). (In Russ.).

Serdobov, N. A. (1968) K voprosu o nekotorykh sotsiologo-lingvisticheskikh protsessakh $\mathrm{v}$ natsional'noi konsolidatsii tuvintsev [On Some Socio-Linguistic Processes of National Consolidation of Tuvans]. Uchenye zapiski / Tuvinskii NIIIaLI. Kyzyl. Vol. 13. Pp. 78-109. (In Russ.). 
Serdobov, N. A. (1980) O roli iazyka i pis'mennosti v natsional'noi konsolidatsii tuvinskogo naroda [On the Role of Language and Writing in the National Consolidation of the Tuvan People]. In: Tuvinskaia pis'mennost' iazyk i literatura [The Tuvan Writing, Language and Literature] / ed. by Iu. L. Aranchyn. Kyzyl, Tuvknigoizdat. 131 p. Pp. 1530. (In Russ.).

Tsybenova, Ch. S. (2013) Sovremennaia iazykovaia situatsiia v Respublike Tyva: sotsiopsikholingvisticheskii aspekt [The Contemporary Linguistic Situation in the Republic of Tyva: The Socio- and Psycholinguistic aspect] : Thesis of Diss.... Candidate of Philology. Ulan-Ude. 24 p.

Submission date: 15.01.2018.

\section{Для циитирования:}

Серээдар Н. М. Тувинский язык как средство общения тувинцев: проблемы и перспективы [Электронный ресурс] // Новые исследования Тувы. 2018, № 1. URL: https://nit.tuva.asia/nit/article/view/752 (дата обращения: дд.мм.гг.). DOI: 10.25178/ nit.2018.1.1

\section{For citation:}

Sereedar N. Ch. Tuvan language as means of communication among Tuvans: Problems and prospects . The New Research of Tuva, 2018, no. 1 [on-line] Available at: https://nit.tuva. asia/nit/article/view/752 (accessed: ...). DOI: 10.25178/nit.2018.1.1 